UDK: 316.47:2-184.3

Izvorni naučni rad

\title{
Safija Perviz
}

Univerzitet u Bihaću

Islamski pedagoški fakultet

safijaperviz2017@gmail.com

\section{RAZLIKE U VELIČINI LIČNOG PROSTORA S OBZIROM NA STEPEN RELIGIOZNOSTI}

\section{Sažetak}

U vrijeme prvobitnih zajednica, kada je mectu ljudima najjači nagon bio nagon za preživljavanjem, čovjek je shvatio da ima bolje šanse ukoliko se priključi nekoj od grupa ili plemena u kojima se tada živjelo. Tako su ljudi, unatoč strahu za svoj život, bili prisiljeni na komunikaciju nesvjesno koristeći sve kanale neverbalne komunikacije. Jedan od tih kanala je i iterpersonalna udaljenost, odnosno lični prostor. Lični prostor je odreden svojim faktorima, obavlja funkcije koje nijedan drugi ljudski mehanizam ne izvršava i obilježen je svojim granicama.

Kada su bile zadovoljene sve fiziološke potrebe i potrebe za pripadanjem, pojavila se vjera, odnosno čovjekova potreba da vjeruje. Tako je nastala današnja religija te religioznost $i$ ona se javlja kada su fiziološke potrebe zadovoljene. Religija $i$ religioznost kao potreba se svrstava $u$ red potreba za sigurnošcu, a najbolje se manifestuje kod ljudi u bezizlaznim situacijama, $u$ situacijama opće katastrofe, kod gubitka voljenih osoba $i$ sl.

U ovom radu ćemo objasniti i definisati pojam ličnog prostora te pojam religije i religioznosti, a onda iznijeti rezultate istraživanja koje smo dobili kada smo ova dva fenomena protkali jedan kroz drugi.

Ključne riječi: lični prostor, neverbalna komunikacija, religioznost

\section{Uvod}

Čovjek je svjesno i spoznajno biće. Biće koje je svakodnevno u interakciji s drugim ljudskim bićima. Kao svjesno biće, čovjek je svjestan sebe, svojih postupaka, ali i drugih ljudi i njihovih postupaka. Kako je čovjek i spoznajno biće, on svakodnevno spoznaje nešto novo, 
pa i sam sebe. Samopromatranjem dolazimo do spoznaja o vlastitom ponašanju, o vlastitim potrebama te spoznajemo koja je naša uloga $u$ određenim svakodnevnim situacijama.

U tim svakodnevnim situacijama, ljudi se oslanjaju jedni na druge, ljudi su usmjereni jedni na druge i svi trenuci koji se dešavaju u životu jednog čovjeka, direktno ili indirektno utiču na život nekog drugog čovjeka. Kako bi što lakše rješavali svoje svakodnevne situacije, ljudi komuniciraju i ta komunikacija se odvija na razne načine; usmenim ili pismenim putem, verbalno ili neverbalno, komunikacija licem u lice ili ona koja se odvija posredstvom komunikacijskih sredstava. Kakva god komunikacija bila i na koji god način se odvijala, svi ćemo se složiti oko jednog, a to je da su sve ljudske interakcije oblik komunikacije.

Naprimjer, svi smo ponekad osjetili nelagodu kad se nađemo $u$ prisustvu neke druge osobe u skučenom prostoru, ili kada se druga osoba nalazi previše blizu nas kada smo usred nekog posla, kada se vozimo u autobusu, ili kada jednostavno stojimo i pričamo. Ova nelagoda svakako bude u većoj ili manjoj mjeri zamijećena od strane našeg sugovornika i ovime mu dajemo do znanja da treba da se pomjeri, što je svakako oblik neverbalne komunikacije čiji značaj se nikako ne smije umanjiti a tek izostaviti iz komunikacijskog procesa. Pomenuta nelagoda nastaje kada druge osobe, u ovom slučaju "uljezi" uzurpiraju naš lični prostor, odnosno prostor koji nas okružuje i omeđen je nevidljivim granicama. Ovaj prostor služi kao naš lični štit, sigurnosna zona, ali on, također, igra veliku ulogu u komunikacijskom procesu i jedan je od kanala neverbalne komunikacije.

Na veličinu ličnog prostora svakako utiču mnogi faktori, ali ono što nam je zaokupilo pažnju, kao i mnogim istraživačima raznih profesija jeste religija, koja je stara koliko i sam čovjek. Pokušavajući otkriti kako to religija, odnosno stepen religioznosti utiče na veličinu ličnog prostora i da li se ova dva fenomena isprepliću ili ne utiču jedan na drugog, došli smo do zanimljivih rezultata.

Snaga religije je sigurno jedna od najvećih sila ovog svijeta, a naš lični prostor je definitivno jedna i jedina "super moć" koji svaki čovjek posjeduje u većoj ili manjoj mjeri. 


\section{O neverbalnoj komunikaciji}

Komunikacija je mnogo više od samih riječi. U komuniciranju, riječi su samo dio poruke, a najveći dio poruke koju šaljemo drugima jeste u neverbalnoj komunikaciji. Ona sadrži govor tijela i ton glasa. Neverbalna komunikacija se još ispoljava u različitom naglašavanju pojedinih glasova pri govoru, tempu govora, ili ritmu izgovorenih riječi, a ne na sadržaju izgovorenih riječi. (Krneta, 2005; 100)

Riječi koje su izgovorene, nisu toliko bitne ako nisu popraćene odgovarajućim tonom glasa, odgovarajućim ritmom i sl., jer obično ljudima nije značajno ono što je rečeno, koliko im je značajan način na koji je to rečeno.

Albert Mehrabianov rad o verbalnoj i neverbalnoj komunikaciji iz '60ih i ranih '70-ih godina, još uvijek se smatra validnim modelom. Istaknuo je da neverbalni aspekti komunikacije kao što je ton glasa, $\mathrm{i}$ neverbalne geste, komuniciraju više od naših izgovorenih riječi. On kaže da će ljudi prije povjerovati našoj neverbalnoj, nego verbalnoj komunikaciji ako se ove dvije nađu u kontradiktornosti. (MTD Training $\&$ Ventus Publishing, 2010)

Mnogi drugi autori također navode značaj neverbalne komunikacije u svakodnevnom ljudskom životu te se onda postavlja pitanje zašto se toliko govori o neverbalnoj komunikaciji, a čini nam se da se ljudi više služe verbalnom? Pa upravo iz razloga jer je neverbalna komunikacija bila prvi oblik sporazumijevanja među prvim ljudima u prvim životnim zajednicama.

Jezik je nastao kasnije, u početku su ljudi komunicirali isključivo neverbalnim znakovima. Osim toga, dok su riječi pod našom svjesnom kontrolom neverbalni znakovi to nisu. (Radenčić, 2013; 8)

Isto tako, koliko god nam se činilo da verbalna komunikacija igra veću ulogu u komunikacijskom procesu, moramo sebi priznati da često budemo pogrešno shvaćeni ili često pogrešno shvatimo druge, kada se ne nalazimo $\mathrm{u}$ istoj prostoriji sa osobom $\mathrm{s}$ kojom komuniciramo, odnosno kada se ta komunikacija vrši putem pomoćnih komunikacijskih sredstava poput telefona i sl. 


\section{Lični prostor i njegovo definiranje}

Lični prostor je područje s nevidljivim granicama koje okružuje tijelo jedne osobe i u koji uljezi ne smiju ući. (Pennington, 2006; 224) Ukoliko se desi neki upad ili uzurpacija ličnog prostora, kod osobe to stvara nelagodu i ona se osjeća ugroženom. Ključna varijabla je ono što se smatra uljezom jer to određuje hoćemo li ili nećemo osjetiti da je naš lični prostor napadnut. (ibidem) Taj prostor možemo opisati kao mjehurić koji štiti naše tijelo.

Prema Wolchoveru (2012), veličina našeg mjehurića zavisi od kulturalnih i individualnih razlika kod ljudi. On navodi da počinjemo razvijati svoj individualni osjećaj za lični prostor oko treće ili četvrte godine života.

Ovo bi značilo, da se kod djece koja su mlađa od tri godine lični prostor ne bi mogao mjeriti, a svakodnevno smo svjedoci da većina djece u dobi od dvije godine neće prići strancu i ostaće u blizini jednog od članova obitelji i sl. Kada autor govori o kulturalnim i individualnim razlikama koje utiču na veličinu ličnog prostora, više o tome će se govoriti u nastavku rada.

Prema Penningtonu (2006), postoje četiri međuljudske udaljenosti ili zone koje je definirao Antropolog Edward Hall:

INTIMNI PROSTOR- do $45 \mathrm{~cm}$ - U području intimnog prostora odvija se blizak kontakt s prijateljima, voljenim osobama te je uobičajen među članovima obitelji. Prisustvo druge osobe je više nego očito, osjetilne informacije su intenzivne te se može osjetiti miris, toplina tijela i dah druge osobe. U komunikaciji se koristi i dodir. (Bogović, 2013; 12) Sam naziv koji je autor iskoristio kako bi definisao ovu zonu ličnog prostora, najbolje ga opisuje, jer je čovjek sklon da svoju intimu dijeli sa najbližim prijateljima, članovima obitelji ili sa voljenim osobama, odnosno životnim partnerima.

LIČNI PROSTOR - do $1 \mathrm{~m}$ i $20 \mathrm{~cm}$ - U ovom području obično se odvija razgovor s prijateljima i poznanicima. Ova zona prihvatljiva je za interakcije koje se odvijaju na javnim mjestima. Za razliku od intimnog prostora, miris i toplina tijela druge osobe ne mogu se osjetiti. Naglašena je upotreba vida i verbalizacije prosječnog intenziteta. Općenito, na toj udaljenosti osobe su manje svjesne osjetilnih informacija nego u intimnom prostoru. (Bogović, 2013; 12) Usporedbe 
radi, vidimo da kako rastu mjere prostora, tako one neminovno zahtjevaju i drugačija "pravila". U ovoj zoni sagovornici se najviše oslanjaju na čulo vida i govora i ne dolazi do prevelikog preklapanja ostalih čula sa već pomenutima. Komunikaciju u ovoj zoni ne remete mirisi, toplina tijela ili dah druge osobe, stoga je ona za razliku od intimne mnogo oskudnija.

DRUŠTVENI/SOCIJALNI PROSTOR - do $3 \mathrm{~m}$ i $60 \mathrm{~cm}$ - Koristi se uglavnom za aktivnosti koje nisu ličnog karaktera, odnosno uključuje interakcije formalnog i poslovnog tipa. Osjetilne informacije su minimalne, vid ne daje tako detaljne informacije kao u zoni ličnog prostora, dodir nije moguć, a komunikacija je uglavnom verbalna i to nešto jačeg intenziteta. (Bogović, 2013; 12) U svijetu biznisa, ništa se ne može postići bez učinkovite komunikacije sa zaposlenicima i klijentima. Kako bi ovakva vrsta komunikacije davala plodove, ona vrlo vjerovatno treba ostati u zoni društvenog/socijalnog prostora.

JAVNI PROSTOR - do $5 \mathrm{~m}$ i $50 \mathrm{~cm}$ - Uključuje kontakte između pojedinca i publike. Pojedinac uglavnom drži govor, predavanje ili je glumac u kazalištu. U toj zoni dominira verbalna komunikacija jačeg intenziteta koju prati i neverbalna, odnosno gestikulacija u svrhu dopunjavanja verbalne. (Bogović, 2013; 12)

Intimni i dobri prijatelji ne čine nam neugodu ako nam priđu blizu, unutar $45 \mathrm{~cm}$ od nas; takva se udaljenost potiče jer nam omogućuje da se lako dodirujemo. Poznanike ili strance obično držimo na ličnoj udaljenosti u više društvenom okruženju u kojem postoji više od dvoje ljudi, a s ljudima unutar $3 \mathrm{~m}$ i $60 \mathrm{~cm}$ često razgovaramo. Javna udaljenost obično je prevelika za razgovor ali je ona u kojoj se događaju prepoznavanje i početni pozdravi. (Pennington, 2006; 224)

Kada govorimo o intimnom prostoru i njegovim granicama, možemo reći i to da iako se potiče na tako malo rastojanje, ponekad se dešava, zavisno od situacije u kojoj se individua nalazi, da nam prisustvo prijatelja ili nekih članova porodice stvara nelagodu.

\section{Religija i religioznost}

Primarno, religioznost se smatra konstitutivnom, antropološkom odrednicom čovjekovog egzistiranja. Proces postajanja ljudskom osobom odgovara procesu razvijanja religioznosti koja je jezgro 
transcendiranja čovjekove biološke prirode. (Vejo, Adilović, Durmić, 2016; 13)

Fenomen religije i religioznosti najviše je plijenio pažnju sociolozima, koji su uvidjeli njenu "neuništivost" pa danas imamo veliki broj literature iz područja sociologije religije.

Religioznost je imanentna samo čovjeku i može se tumačiti u širem i užem smislu. Kako Pranjević navodi, religioznost u širem smislu je ljudska usmjerenost na samonadilaženje, nemirenje s tvrdnjom da se ljudski život smatra samo rasponom od rođenja do smrti, nego da čovjekovo biće "bezuvjetno teče u Boga". ( Ćatić, 2005)

U mnogim religijama se vjeruje da ljudi nastavljaju život i poslije smrti, ali da se on značajno razlikuje od života kojeg živimo na zemlji.

U islamu se vjeruje da je prvi čovjek stvoren Božijom rukom i da je u njegovu dušu i postojanje utkano Božijeg duha jer je Bog (Allah, dž.š.) bio taj koji je prvom čovjeku, Ademu, udahnuo dušu, dok ostalim ljudima dušu udahnjuju meleci. Možda baš iz ovog vjerovanja autor crpi tvrdnju da čovjekovo biće "bezuvjetno teče u Boga."

Njenu snagu smo uviđali kroz cijelu historiju, i u dobrom i u lošem svjetlu. U nekim periodima, na nekim geografskim podnebljima, njeno djelovanje je bilo manje vidljivo ili se barem spolja tako činilo. Taman kad su neki povjerovali u priču „od danas u našoj kući više nema Boga“, došlo je do novog ciklusa, klatno se zanjihalo u drugom pravcu. Od kraja osamdesetih i početkom devedesetih godina prošlog vijeka, na teritoriji bivše Jugoslavije, sa padom socijalizma, bilježimo drastično drugačiji odnos prema religiji. U globalu, postotak onih koji su se prije devedesetih izjašnjavali kao ,nereligiozni“ približno je jednak procentu „religioznih“" sa početkom devedesetih i kasnije. (Dušanić, 2007; 9)

Prema nekim sociolozima, religija predstavlja harmoniju u društvenim odnosima, dok isto tako imamo grupu sociologa koji na religiju gledaju kao svojstveni opijum za narod, smatrajući da je ona samo nastavak onog što je radila Srednjovjekovna crkva.

Religijska uvjerenja ove ili one vrste postoje u svakom društvu koje poznajemo. Njihov broj i raznolikost su naizgled neizmjerni. Iz tog razloga, svaka definicija religije trebala bi obuhvatiti sve te raznolikosti. Međutim, vrlo je teško dati definiciju koja bi bila dovoljno široka da 
obuhvati sve te raznolikosti, a da istodobno ne obuhvati fenomene za koje obično sami ne smatramo da su religije. (Haralambos, Holborn, 2002)

Religija je, kao što smo rekli, potreba svakog čovjeka, odnosno njegovo vezivanje za određena učenja koja neka religija propagira. Religija, sa sociologijske strane, se određuje kao vjerovanje u Nadnaravno i sveto izraženo religijskim običajima, obredima i simbolima o kojima se skrbe religijske organizacije i religijsko vodstvo, i koje sljedbenike date religije opskrbljuje ćudorednim definicijama. (Cvitković, 2007; 31) Religiju možemo nazvati sistemom života, odnosno skupom pravila putem kojih pojedinac uređuje svoj život i po kojima se vodi. S druge strane, religioznost je širi pojam i dinamičan proces.

Religioznost se može shvatiti kao lična usmjerenost u slijeđenju određene ideje vezane uz transcendentne sadržaje, a to se može manifestovati kao izrazita motiviranost za činjenje određenih postupaka u svakodnevnom životu. (Z. Leutar i I. Leutar, 2010)

Ona se razlikuje od pojedinca do pojedinca, kada on može biti više ili manje religiozan, isto kao i grupe unutar društva koje slijede istu religiju, ali neki to rade s većom, a neki s manjom dozom religioznosti.

Religioznost se više odnosi na subjektivno i individualno, posebno na iskustvo pojedinca tj. na njegov lični ili individualni odnos prema Bogu, odnosno na sposobnost da komunicira s Bogom. (Z. Leutar i I. Leutar, 2010)

\section{METODOLOGIJA}

\section{Problem istraživanja}

Problem ovog istraživanja jeste lični prostor. Lični prostor je područje s nevidljivim granicama koje okružuje tijelo jedne osobe i u koje uljezi ne smiju ući. (Pennington, 2006) Ukoliko se desi neki upad ili uzurpacija ličnog prostora, kod osobe to stvara nelagodu, i ona se osjeća ugroženom. On zavisi od mnogih faktora i s mnogim sociološkim fenomenima se može dovoditi u vezu. U mnogim pokušajima, autori su vršili istraživanja na osobama koje imaju problema sa socijalnim uklapanjem u društvo, poput djece sa autizmom, emotivnih problema $\mathrm{i}$ 
sl., kod muškaraca i kod žena kako bi napravili razliku, te su u mnogim drugim okolnostima rađena istraživanja o ličnom prostoru. O njemu su govorili mnogi autori pa danas zahvaljujući njima imamo veliki broj istraživanja na ovu temu. Kako je religioznost ono što odlikuje svakog čovjeka i svako društvo, a kako je lični prostor "moć" koju ima svaki čovjek, odlučili smo se da ovo istraživanje ide baš u tom pravcu, da isprepletemo jedno i drugo, stoga je prvo ovakvog karaktera.

Religioznost možemo opisati kao sistem vrednovanja određenih ponašanja, stvari, radnji, ali i sistem življenja. Ona je sveprisutan faktor ljudskog života i kao takva određuje i regulira sva ljudska ponašanja. Samim tim što je ona jedan, nazovimo je, regulator ponašanja, ona ga regulira i u interakciji s drugima, pa se stoga da povezati sa mnogim socijalnim ponašanjima i fenomenima kao što je lični prostor.

\section{Predmet istraživanja}

Predmet ovog istraživanja jesu moguće razlike $u$ veličini ličnog prostora s obzirom na stepen religioznosti sudionika.

\section{Cilj istraživanja}

Osnovni cilj ovog istraživanja jeste ispitati postoje li razlike u veličini ličnog prostora s obzirom na stepen religioznosti.

Sporedni ciljevi jesu:

- Ispitati da li postoje razlike u veličini ličnog prostora $\mathrm{s}$ obzirom na spol pomoćnih eksperimentatora .

- Ispitati i utvrditi da li postoje razlike u veličini ličnog prostora s obzirom na status veze sudionika.

\section{Zadaci istraživanja}

- Istražiti i utvrditi postoje li razlike u veličini ličnog prostora s obzirom na stepen religioznosti.

- Utvrditi postoje li razlike u veličini ličnog prostora s obzirom na spol pomoćnih eksperimentatora

- Istražiti i utvrditi postoje li razlike u veličini ličnog prostora s obzirom na status veze sudionika. 


\section{Hipoteze}

1. Postoje razlike u veličini ličnog prostora s obzirom na stepen religioznosti.

2. Postoje razlike u veličini ličnog prostora s obzirom na spol pomoćnih eksperimentatora.

3. Postoje razlike u veličini ličnog prostora s obzirom na status veze sudionika.

\section{Metode rada i tehnike istraživanja}

U ovom istraživanju korišten je metod eksperimenta i statistički metod.

Tehnike koje su korištene za prikupljanje potrebnih podataka o uzorku su:

- tehnika anketiranja

- deskriptivna skala stavova

- tehnika zaustavljanja

\section{Instrumenti istraživanja}

Prilikom mjerenja ličnog prostora korištena je tehnika zaustavljanja, a za ovu tehniku korišten je metar i traka sa označenim centimetrima (širine $3 \mathrm{~cm}$ a dužine $3 \mathrm{~m}$ u sva četiri pravca prilaženja, tj. 6x6), te zapisnik o prikupljenim mjernim vrijednostima. Mjerna vrijednost je predstavljala razdaljinu od polovine stopala sudionika, do polovine stopala pomoćnog eksperimentatora.

Potrebni podaci o sudionicima dobijeni su putem anketiranja, odnosno putem sociodemografskog upitnika.

Za dobijanje stepena religioznosti, koristili smo se deskriptivnom skalom likertovog tipa. Skala RELIG\&BM-2004 (Milosavljević, 2007), sastoji se od 15 čestica (tvrdnji) sa vrijednostima od 1 do 5. Prema Milosavljeviću (2007), pouzdanost ove skale provjerena je u više istraživanja i kreće se od apha 81-.86. 


\section{Uzorak}

Uzorak u ovom istraživanju sačinjavaju studenti (muški i ženski) sa fakulteta Univerziteta u Bihaću. Uzorak obuhvata $\mathrm{N}=172$, tj. studente I, II, III i IV godine studija. Prilikom odabira uzorka, korišten je prigodni uzorak.

Tabela 1: Struktura uzorka

\begin{tabular}{|c|c|c|c|c|c|c|}
\hline \multirow{2}{*}{ Fakultet / škola } & \multicolumn{2}{|c|}{ Muški } & \multicolumn{2}{|c|}{ Ženski } & \multicolumn{2}{|c|}{ Ukupno } \\
\hline & $\mathrm{N}$ & $\%$ & $\mathrm{~N}$ & $\%$ & $\mathrm{~N}$ & $\%$ \\
\hline Islamski pedagoški fakultet & 26 & 45,6 & 31 & 54,4 & 57 & 33,2 \\
\hline Biotehnički fakultet & 13 & 38,2 & 21 & 61,8 & 34 & 19,8 \\
\hline Ekonomski fakultet & 8 & 25,8 & 23 & 74,2 & 31 & 18,0 \\
\hline Visoka zdravstvena škola & 16 & 44,4 & 20 & 55,6 & 36 & 20,9 \\
\hline Pedagoški fakultet & 9 & 64,3 & 5 & 35,7 & 14 & 8,1 \\
\hline Ukupno & 72 & 41,9 & 100 & 58,1 & 172 & 100,0 \\
\hline
\end{tabular}

\section{Varijable istraživanja}

Zavisnu varijablu u ovom istraživanju čini lični prostor, odnosno veličina ličnog prostora. Ova varijabla je racio-intervalna, kontinuirana i numerička, a iskazuje se zbirom površina četiri pravougla trougla čije su katete mjerene dužine odstojanja za desno, lijevo, naprijed i nazad od sudionika do pomoćnog eksperimentatora. Ove vrijednosti su u kvadratnim metrima

Ova varijabla ima dva modaliteta:

a) Veličina ličnog prostora kada je pomoćni eksperimentator osoba istog spola kao i sudionik - oznaka LPIS,

b) Veličina ličnog prostora kada je pomoćni eksperimentator osoba suprotnog spola u odnosu na sudionika - oznaka LPSS

Nezavisnu varijablu predstavlja stepen religioznosti sudionika $u$ istraživanju. Ova varijabla je također racio-intervalna, kontinuirana i numerička, a iskazuje se ukupnim skorom na Skali religioznosti, gdje 
se teorijske vrijednosti mogu kretati u intervalu 15 do 75; veći ukupan rezultat ukazuje na veći stepen religioznosti.

Posredujuće varijable u ovom istraživanju su spol sudionika i status veze. Spol je varijabla nominalnog tipa sa dva atributivna obilježja (muško / žensko), a status veze, također, nominalna kategorijalna varijabla sa četiri kategorije: u vezi, slobodan / na, zaručen / na i ostalo.

\section{REZULTATI I DISKUSIJA}

\section{Odnos ličnog prostora i stepena religioznosti}

Tabela 2: Pokazatelji deskriptivne statistike za Skalu religioznosti

\begin{tabular}{lcccccccc}
\hline \multirow{2}{*}{ Skala religioznosti } & $\mathrm{M}$ & $\mathrm{SD}$ & Med & Min & Max & Sk & Ku & $\alpha$ \\
\cline { 2 - 8 } & 51,35 & 6,48 & 52 & 19 & 68 & -1.18 & 5.19 & .775 \\
\hline
\end{tabular}

Legenda:

$\mathrm{M}=$ aritmetička sredina

$\mathrm{SD}=$ standardna devijacija

Med $=$ medijan

Min $=$ ostvaren minimalni rezultat

Max $=$ ostvaren maksimalan rezultat

$\mathrm{Sk}=$ skjunis

$\mathrm{Ku}=$ kurtosis

$\alpha=$ Krombahov koeficijent pouzdanosti

Ostvareni ukupan rezultat na Skali religioznosti (Tabela 2) kreće se u intervalu 19 do 68 (teorijski interval je 15 do 75), a odnos aritmetičke sredine i medijana (Med $>M$ ) pokazuje da nešto više od 50\% ispitanika na ovoj skali ima ukupan skor veći od prosjeka, odnosno, da djelimično preovladavaju viši rezultati, da je krivulja nešto više nagnuta udesno, na šta ukazuje i vrijednost skjunisa. Pozitivna vrijednost za kurtosis $(\mathrm{Ku}$ = 5.19) pokazuje da je distribucija šiljatija od normalne, odnosno, da se rezultati više gomilaju oko središnje vrijednosti. Koeficijent 
pouzdanosti $(\alpha>0.7)$ ukazuje na visoku pouzdanost mjerenja (Palant, 2009; 97)

Za potrebe testiranja radne hipoteze broj 1. numeričke vrijednosti za ukupan skor na Skali religioznosti iskazane su u kategorijama na osnovu aritmetičke sredine (M) i standardne devijacije (SD):

- nizak stepen religioznosti: rezultat manji od M - 1 SD

- umjeren stepen religioznosti: rezultat $\mathrm{u}$ intervalu $\mathrm{M} \pm 1 \mathrm{SD}$

- visok stepen religioznosti: rezultat veći od M + $1 \mathrm{SD}$

Tabela 3: Pokazatelji za stepen religioznosti i veličinu ličnog prostora kada je pomoćni eksperimentator osoba istog spola (LPIS) - rezultati primjene postupka jednofaktorske univarijantne analize varijanse (ANOVA) za uzorak u cjelini

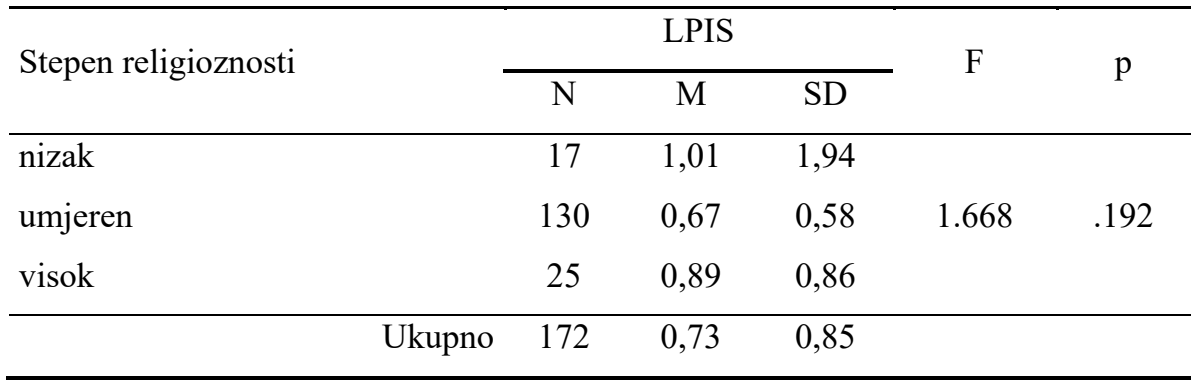

Dobijeni rezultati analize (Tabela 3) pokazuju da su u prosjeku najveću vrijednost ličnog prostora, kada je pomoćni eksperimentator osoba istog spola (LPIS), ostvarili ispitanici sa niskim stepenom religioznosti $(\mathrm{M}=1,01)$ uz istovremenu najveću disperziju $(\mathrm{SD}=1,94)$. Ispitanici sa umjerenim stepenom religioznosti ostvarili su najveću homogenost rezultata $(\mathrm{SD}=0,58)$, ali i najmanju prosječnu vrijednost ličnog prostora $(\mathrm{M}=0,67)$.

Tabela 4: Pokazatelji za stepen religioznosti i veličinu ličnog prostora kada je pomoćni eksperimentator osoba suprotnog spola (LPSS) - rezultati primjene postupka jednofaktorske univarijantne analize varijanse (ANOVA) za uzorak u cjelini

\begin{tabular}{lllllll}
\hline \multirow{2}{*}{ Stepen religioznosti } & \multicolumn{3}{c}{ LPSS } & & F & $\mathrm{p}$ \\
\cline { 2 - 4 } & $\mathrm{N}$ & $\mathrm{M}$ & $\mathrm{SD}$ & & \\
\hline
\end{tabular}




\begin{tabular}{lccccc}
\hline nizak & 17 & 1,08 & 1,54 & & \\
umjeren & 130 & 1,46 & 1,31 & 2,365 & .097 \\
visok & 25 & 1,99 & 1,83 & & \\
\hline Ukupno & 172 & 1,50 & 1,43 & & \\
\hline
\end{tabular}

Rezultati analize prikazani u Tabeli 4 pokazuju da su u prosjeku najveću vrijednost ličnog prostora, kada je pomoćni eksperimentator osoba suprotnog spola (LPSS), ostvarili ispitanici sa visokim stepenom religioznosti $(\mathrm{M}=1,99)$ uz istovremenu najveću disperziju $(\mathrm{SD}=1,83)$. Ispitanici sa niskim stepenom religioznosti ostvarili su najmanju prosječnu vrijednost u ovoj dimenziji ličnog prostora $(\mathrm{M}=1,08)$, a najveću homogenost rezultata $(\mathrm{SD}=1,31)$ ostvarili su ispitanici sa umjerenim stepenom religioznosti.

S obzirom da izvršena analiza nije pokazala statistički značaj uticaj stepena religioznosti na razlike u veličini ličnog prostora, za potrebe testiranja polazne radne hipoteze broj 1. za uzorak u cjelini, izvršena je i analiza zajedničkog uticaja spola ispitanika, kao posredujuće varijable. Odnosno, bilo je potrebno provjeriti da li u grupama ispitanika s obzirom na njihov spol, postoje razlike u prosječnoj veličini ličnog prostora s obzirom na nivo religioznosti, budući da se te razlike nisu pokazale statistički značajnim za uzorak u cjelini.

Rezultati izvršene analize pokazali su da se razlike aritmetičkih sredina ličnog prostora između muških i ženskih ispitanika, kada je pomoćni eksperimentator osoba istog spola (LPIS), nisu pokazale statistički značajnim ni u jednoj od grupa s obzirom na stepen religioznosti, ali je zajednički uticaj spola i stepena religioznosti blizu nivoa značajnosti ( $\mathrm{p}=.052)$.

$\mathrm{Na}$ osnovu dobijenih rezultata primjenom dvofaktorske univarijantne analize varijanse, može se zaključiti da se razlike aritmetičkih sredina u prosječnoj veličini ličnog prostora između muških i ženskih ispitanika, kada je pomoćni eksperimentator osoba suprotnog spola (LPSS), nisu pokazale statistički značajnim ni $u$ jednoj od grupa ispitanika s obzirom na stepen religioznosti, ali je zaseban uticaj spola u ovom slučaju viši $(\mathrm{p}=.062)$ u odnosu na situaciju kada je pomoćni eksperimentator osoba istog spola. 
Rezimirajući rezultate izvršene analize, može se zaključiti da stepen religioznosti, kao nezavisna varijabla, nema statistički značajan uticaj na razlike u prosječnoj vrijednosti ličnog prostora, s obzirom na spol pomoćnog eksperimentatora, za uzorak u cjelini, niti odvojeno za grupe ispitanika prema njihovom spolu.

\section{Odnos ličnog prostora i spola pomoćnog eksperimentatora}

Polaznom radnom hipotezom broj 2. pretpostavljeno je da postoji razlika u prosječnoj vrijednosti ličnog prostora $\mathrm{s}$ obzirom na spol pomoćnih eksperimentatora. Za testiranje ove hipoteze korišten je $\mathrm{t}$ test uparenih uzoraka (Paired - Samples T - test), pošto se radi o dva mjerenja na istom uzorku pod različitim uslovima.

Tabela 5: Pokazatelji za testiranje značajnosti razlika u prosječnoj vrijednosti ličnog prostora s obzirom na spol pomoćnih eksperimentatora za uzorak $u$ cjelini

\begin{tabular}{lcccccc}
\hline Lični prostor & $\mathrm{M}$ & $\mathrm{SD}$ & $\mathrm{MD}$ & $\mathrm{df}$ & $\mathrm{t}$ & $\mathrm{p}$ \\
\hline LPIS & 0,734 & 0,854 & 0,764 & 171 & 8,754 & .000 \\
LPSS & 1,498 & 0,427 & & & & \\
\hline
\end{tabular}

Rezultati izvršene analize (Tabela 5) pokazuju za uzorak u cjelini da je prosječna vrijednost ličnog prostora $(\mathrm{M}=1,498)$ veća kada je pomoćni eksperimentator osoba suprotnog spola, u odnosu na prosječnu vrijednost $(\mathrm{M}=0,734)$ kada je pomoćni eksperimentator osoba istog spola. Ova razlika se pokazala statistički značajnom $(\mathrm{t}=8,754 ; \mathrm{p}=$ .000 ), na osnovu čega se sa $99 \%$ sigurnosti može tvrditi da će u populaciji koju predstavlja ovaj uzorak, prosječna veličina ličnog prostora biti veća kada je pomoćni eksperimentator osoba suprotnog spola u odnosu na prosječnu veličinu ličnog prostora kada je pomoćni eksperimentator osoba istog spola, čime je polazna radna hipoteza broj 2. u cjelosti potvrđena

S obzirom da je potvrđen uticaj spola pomoćnog eksperimentatora na veličinu ličnog prostora, za uzorak u cjelini, taj se uticaj (prema Pallant, 2009; 243) iskazuje Eta - kvadratom, a izračunava se po formuli:

$$
\text { Eta }- \text { kvadrat }=\mathrm{t}^{2} /\left(\mathrm{t}^{2}+\mathrm{N}-1\right)
$$


U ovom slučaju vrijednost za Eta - kvadrat iznosi 0,31. Koen (prema Pallant, 2009; 243) daje slijedeće granice za tumačenje vrijednosti Eta - kvadrata:

- $\quad 0,01-0,05=$ mali uticaj

- $\quad 0,06-0,13=$ umjeren uticaj

- 0,14 i više $=$ velik uticaj

Prema ovoj skali može se zaključiti da spol pomoćnog eksperimentatora ima veoma velik uticaj na vrijednost ličnog prostora, odnosno, da će prosječna vrijednost općenito, bez uzimanja u obzir drugih obilježja ispitanika, biti uvijek veća ako je pomoćni eksperimentator osoba suprotnog spola.

Uticaj spola pomoćnog eksperimentatora na veličinu ličnog prostora potvrđen je za uzorak u cjelini. Potrebno je, međutim, ispitati kako spol pomoćnog eksperimentatora utiče na veličinu ličnog prostora ispitanika jednog i drugog spola, odnosno, da li je spol pomoćnog eksperimentatora relevantan prediktorski faktor razlika u veličini ličnog prostora i kod jednog i kod drugog spola ispitanika. Ako se uporede prosječne vrijednosti ličnog prostora kada je pomoćni eksperimentator osoba suprotnog spola (LPSS), uočava se da ispitanici ženskog spola pokazuju veću osjetljivost na ovu okolnost, jer su ostvarili veću prosječnu vrijednost ličnog prostora $(\mathrm{M}=1,759) \mathrm{u}$ odnosu na ispitanike muškog spola $(\mathrm{M}=1,135)$. Ova razlika $(\mathrm{MD}=0,624)$ se pokazala statistički značajnom na nivou .01 $(\mathrm{t}=2,889 ; \mathrm{p}=.004 ; \mathrm{p}<.01)$, što znači da se sa $99 \%$ sigurnosti može očekivati i u populaciji veća prosječna vrijednost ličnog prostora kod ženskih ispitanika ako je pomoćni eksperimentator muškog spola, u odnosu na ispitanike muškog spola ako je pomoćni eksperimentator osoba ženskog spola. Suprotan spol pomoćnog eksperimentatora, dakle, ima veći uticaj na lični prostor kod osoba, ženskog nego muškog spola.

Dobijena vrijednost za Eta - kvadrat u ovom slučaju iznosi 0,05, što je po Koenovoj skali (Pallant, 2009; 243) na samoj granici između malog i umjerenog uticaja. Dakle, kod ispitanika ženskog spola, uticaj pomoćnog eksperimentatora kada je on osoba muškog spola, može objasniti $5 \%$ varijanse u distribuciji rezultata ličnog prostora $(0,05=$ $5 \%)$. 


\section{Odnos ličnog prostora prema statusu veze sudionika}

Polaznom radnom hipotezom broj 3. pretpostavljeno je da postoje razlike u veličini ličnog prostora s obzirom na status veze sudionika. Pošto je status veze kategorijska varijabla sa četiri modaliteta: a) u vezi, b) slobodan/a, c) zaručen/a i d) ostalo, a veličina ličnog prostora racio - intervalna, kontinuirana i numerička varijabla sa dvije dimenzije: a) veličina ličnog prostora kada je pomoćni eksperimentator osoba istog spola (LPIS) i b) veličina ličnog prostora kada je pomoćni eksperimentator osoba suprotnog spola (LPSS), za potrebe testiranja ove radne hipoteze, za uzorak u cjelini, korišten je postupak univarijantne jednofaktorske analize varijanse (ANOVA).

Tabela 6: Pokazatelji za veličinu ličnog prostora kada je pomoćni eksperimentator osoba istog spola (LPIS) u odnosu na status veze ispitanika - rezultati primjene postupka jednofaktorske univarijantne analize varijanse (ANOVA) za uzorak u cjelini

\begin{tabular}{|c|c|c|c|c|c|}
\hline \multirow{2}{*}{ Status veze } & \multicolumn{3}{|c|}{ LPIS } & \multirow{2}{*}{$\mathrm{F}$} & \multirow{2}{*}{$\mathrm{p}$} \\
\hline & $\mathrm{N}$ & $\mathrm{M}$ & $\mathrm{SD}$ & & \\
\hline u vezi & 66 & 0,682 & 0,719 & \multirow{4}{*}{0,227} & \multirow{4}{*}{.877} \\
\hline slobodan / a & 98 & 0,754 & 0,965 & & \\
\hline zaručen / a & 4 & 0,945 & 0,341 & & \\
\hline \multirow[t]{2}{*}{ ostalo } & 4 & 0,897 & 0,215 & & \\
\hline & 172 & 0,734 & 0,854 & & \\
\hline
\end{tabular}

Za uzorak u cjelini (Tabela 6) najveća prosječna vrijednost ličnog prostora kada je pomoćni eksperimentator osoba istog spola (LPIS) je u grupi ispitanika koji su zaručeni $(M=0,945)$, a najmanja $(M=0,682)$ kod ispitanika koji su u vezi. Međutim, ostvarena vrijednost za $\mathrm{F}$ omjer $(\mathrm{F}=0,227 ; \mathrm{p}=.877 ; \mathrm{p}>.05)$ pokazuje da se nijedna od razlika aritmetičkih sredina za LPIS među grupama ispitanika s obzirom na status veze, nije pokazala statistički značajna.

Međutim, stvarena vrijednost za $\mathrm{F}$ - omjer u slučaju kada je pomoćni eksperimentator osoba suprotnog spola $(\mathrm{F}=4,615 ; \mathrm{p}=.004 ; \mathrm{p}<.01)$ pokazuje da postoje statistički značajne razlike u aritmetičkim 
sredinama ličnog prostora LPSS među grupama s obzirom na status veze.

Primjenom Scheffe - testa utvrđeno je da su statistički značajne razlike u aritmetičkim sredinama ličnog prostora kada je pomoćni eksperimentator osoba suprotnog spola (LPSS) jedino između grupa ispitanika koji su:

a) $\mathrm{u}$ vezi $(\mathrm{M}=1,390)$ i onih koji su zaručeni $(\mathrm{M}=3,328)$ : $\mathrm{MD}=$ 1,$938 ; \mathrm{p}=.044 ; \mathrm{p}<.05 \mathrm{i}$

b) slobodni $(M=1,426)$ i onih koji su zaručeni (3,328): $M D=1,902$; $\mathrm{p}=.048 ; \mathrm{p}<.05$

Potrebno je, dakle, ispitati da li status veze različito utiče na veličinu ličnog prostora u grupama ispitanika s obzirom na njihov spol, odnosno, da li se uticaj statusa veze na lični prostor LPSS jednako odražava na ispitanike jednog i drugog spola.

Tabela 7: Pokazatelji za zajednički uticaj spola i statusa veze na veličinu ličnog prostora kada je pomoćni eksperimentator osoba suprotnog spola (LPSS)

\begin{tabular}{lcrr}
\hline Varijable & df & F & p \\
\hline Status veze & 3 & 4,340 & .006 \\
Spol & 1 & 0,160 & .690 \\
Status veze * spol & 2 & 2,296 & .104 \\
\hline
\end{tabular}

Ispitivanje zasebnog uticaja spola i statusa veze, te uticaja interakcije ovih varijabli na veličinu ličnog prostora kada je pomoćni eksperimentator osoba suprotnog spola (Tabela 7) pokazalo je da postoji značajan zasebni uticaj statusa veze na veličinu ličnog prostora LPSS: $F_{(3,172)}=4,340 ; p=.006 ; p<.01$, ali ne i značajan zasebni uticaj spola ispitanika: $\mathrm{F}_{(1,172)}=0,160 ; \mathrm{p}=.690 ; \mathrm{p}>.05$. Uticaj interakcije spola i statusa veze na veličinu ličnog prostora nije značajan: $F_{(2,172)}=$ 2,$296 ; p=.104 ; p>.05$, što znači da nema značajne razlike u uticaju statusa veze na ovu veličinu ličnog prostora između muških i ženskih ispitanika. 
Sumirajući rezultate izvršene kvantitativne i kvalitativne analize za potrebe testiranja radne hipoteze broj 3. o donosu statusa veze i ličnog prostora, može se zaključiti da je ova hipoteza potvrđena samo u slučaju kada je pomoćni eksperimentator osoba suprotnog spola, a u slučaju kada je pomoćni eksperimentator osoba istog spola, ova se hipoteza odbacuje.

\section{ZAKLJUČCI}

Predmet ovog istraživanja je bio odnos nivoa religioznosti i veličine ličnog prostora u studentskoj populaciji . Religioznost danas, $\mathrm{u}$ društvenom kontekstu, predstavlja za nauku i praksu izuzetno značajan psihološki i sociološki fenomen i izazov. Lični prostor za svaku osobu predstavlja mjerljivo svojstvo ličnosti, koje osoba doživljava kao najmanju razdaljinu ili distancu koju podnosi kao blizinu druge osobe u komunikaciji i kontaktu kada joj ta druga osoba prilazi sprijeda, ozada, sa lijeve ili desne strane i ima dva modaliteta: kada je ta druga osoba istog spola ili kada je suprotnog spola.

Analizom dobijenih rezultata, primjenom postupaka statističkog zaključivanja, utvrđeno je sljedeće:

1. Stepen religioznosti, kao nezavisna varijabla, nema statistički značajan uticaj na razlike u prosječnoj vrijednosti ličnog prostora, s obzirom na spol pomoćnog eksperimentatora, za uzorak u cjelini, niti odvojeno za grupe ispitanika prema njihovom spolu. Na osnovu te analize pouzdano se može odbaciti postavljena hipoteza broj 1 o postojanju razlika $\mathrm{u}$ veličini ličnog prostora $\mathrm{s}$ obzirom na stepen religioznosti i prihvatiti nulta hipoteza.

2. U vezi posredujućeg uticaja spola pomoćnog eksperimentatora na veličinu ličnog prostora potvrđeno je, za uzorak u cjelini, da je prosječna veličina ličnog prostora statistički značajno veća kada je pomoćni eksperimentator osoba suprotnog spola u odnosu na prosječnu veličinu ličnog prostora kada je pomoćni eksperimentator osoba istog spola, čime je polazna radna hipoteza broj 2 u cjelosti potvrđena.

Zasebno između grupa muških i ženskih ispitanika nije potvrđena statistički značajna razlika u prosječnoj veličini ličnog prostora ako je pomoćni eksperimentator osoba istog spola, ali ako je pomoćni eksperimentator osoba suprotnog spola, to će imati statistički značajno 
veći uticaj na ispitanike ženskog, nego na ispitanike muškog spola. Suprotan spol pomoćnog eksperimentatora, dakle, ima veći uticaj na lični prostor kod osoba ženskog nego kod osoba muškog spola.

3. Sumirajući rezultate izvršene kvantitativne i kvalitativne analize za potrebe testiranja radne hipoteze broj 3 o donosu statusa veze i ličnog prostora, ova hipoteza je potvrđena samo u slučaju kada je pomoćni eksperimentator osoba suprotnog spola, a u slučaju kada je pomoćni eksperimentator osoba istog spola, ova se hipoteza odbacuje i prihvata nulta hipoteza.

\section{Prijedlozi}

Kroz navedene definicije u radu mogli smo vidjeti koliko su ljudi većinom nesvjesno svjesni svog ličnog prostora. Kada bi više znali o ovom fenomenu, bili bi još svjesniji tog mjehurića koji nas okružuje i čuva od opasnih situacija, nelagodnih socijalnih interakcija, ili nas katkad dovodi do konflikata te uznemirenosti ukoliko neko uzurpira naš prostor.

Možemo slobodno ovaj fenomem uporediti sa čuvanjem i brigom o teritoriju kod životinja. Ono što je još bitno navesti jeste da se o ovom fenomenu može istraživati još mnogo vremena i u mnogim pravcima, te tražiti povezanost između zaštite ličnog prostora i nekih ljudskih ponašanja.

Ovakva istraživanja bi trebala ići u pravcu zaštite ličnog prostora kod onih pojedinaca koji su ga malo ili nikako svjesni. Nesvjesnost o prostoru koji nas okružuje a koji je naš lični, može imati kobne posljedice na pojedinca, a ponajviše na djecu. U radu smo vidjeli da djeca postaju svjesna svog ličnog prostora sa tri ili četiri godine života, ali nažalost, u svim pravilima imamo odstupanja, pa se više moramo brinuti o tim odstupanjima. Lični prostor treba istraživati u svim područjima ljudskog djelovanja, te kod svih kategorija ljudi, i upoznati pojedince o tom fenomenu jer vjerujemo da neki ljudi nikad nisu čuli za zaštitni mjehurić koji ga okružuje i koji im omogućuje lakšu socijalnu interakciju.

Ono što bi u ovom istraživanju dalo drugačije rezultate, moglo bi da bude veličina uzorka i njegova struktura, ali i samo uzimanje mjera. Bilo bi zanimljivo istražiti i uporediti eventualne razlike kada bi se u 
vezu dovele mjere uzete samo od prednje strane (smjer prilaženja) sudionika muškog i ženskog spola. U tom slučaju sudionik i pomoćni eksperimentator su licem u lice i već dolazi do uspostavljanja kontakta očima što bi značilo da su oni samim tim u jednom vidu neverbalne komunikacije, s obzirom da je kontakt očima kao i lični prostor jedan od kanala takve komunikacije.

Tokom istraživanja uočene su mnoge promjene fiziološke priode kod sudionika muškog spola, koje su bile očit primjer nelagode, kao što je crvenilo u licu, spuštanje pogleda i stiskanje dlanova u pesnicu, ali unatoč toj očitoj nelagodi nisu htjeli da zaustave pomoćnog eksperimentatora ženskog spola u njenom prilaženju. Bilo bi zanimljivo istražiti tu pojavu s područja psihologije ličnosti i sl.

\section{Literatura:}

1. Aronson, E., Wilson, T.D., Akert, R.M. (2005). Socijalna psihologijačetvrto izdanje. Zagreb: Mate

2. Aziraj, V., Ćeranić, S. (2013). Differences in the size of personal space between persons with anxious and persons with psychotic disorders. Psychiatria Danubina, Vol. 25, No. 2, (str.163-169)

3. Bailenson, J.N., Blascovich, J., Beal, A.C., Loomis, J.M. (2001). Equilibrium Theory Revisited: Mutual Gaze and Personal Space in Virtual Environments. Presence, Vol. 10, No. 6, (str.583-598)

4. Baldassare, M., Feller, S. (1975). Cultural Variations in Personal Space:Theory, Methods and Evidence. ETHOS, Vol. 3, No. 4, (str.481503)

5. Bogović, A. (2013). Osobni prostor oboljelih od posttraumatskog stresnog poremećaja. Sveučilište u Zagrebu: Objavljeni doktorski rad, (str.2,3,4,6,7,8,12,24)

6. Burgoon, J.K., Jones, S.B. (1976). Toward a Theory of Personal Space Expectations and Their Violations. Human Communication Research, Vol. 2, No. 2, (str.131-146)

7. Cvitković, I. (2007). Sociologija religije-četvrto izdanje. Sarajevo: DES (str.31)

8. Ćatić, R. (2005).Osnovi porodične pedagogije. Zenica: Pedagoški fakultet u Zenici

9. Dušanić, S. (2007). Psihološka istraživanja religioznosti . Banja Luka: Filozofski fakultet Banja Luka (str. 9,16,18,27, 70,78) 
10. Gessaroli, E., Santelli, E., di Pellegrino, G., Frassinetti, F. (2013). Personal Space Regulation in Childhood Autism Spectrum Disorders. PLoS ONE, Vol. 8, No. 9 , e74952

11. Graziano, M.S.A., Cooke, D.F. (2006). Parieto-frontal interactions, personal space, and defensive behavior. Neuropsychologia, Vol.44, No. 6, (str.845-859

12. Hall, E.T. (1966). The hidden dimension. Garden City: Doubleday (str.13-14)

13. Hall, E.T. (1968). Proxemics. Current Anthropology, Vol. 9, No. 2/3, (str.83-108)

14. Haralambos, M., Holborn, M. (2002). Sociologija: teme i perspektive, Zagreb: Golden marketing

15. Jakšić, M. (2011). Invazija u osobni prostor. Portal za osobni i profesionalni razvoj http://www.centaruspjeha.com/invazija-u-osobniprostor/

16. Kinoe, Y., Mizuno, N. (2015). Situational Transformation of Personal Space. Springer International Publishing Switzerland, Part II, LNCS 9173, (str.15-24)

17. Krneta, D. (2005). Socijalna psihologija: udžbenik za studente menadžmenta. Banja Luka: Fakultet za poslovni inženjering i poslovni menadžment Banja Luka (str. 100-101)

18. Leutar, Z., Leutar, I. (2010). Religioznost i duhovnost u socijalnom radu. Crkva u svijetu, Vol.45, br. 1, (str.78-103)

19. Middlemist, R.D., Matter, F.C., Knowles, S.E. (1976). Personal Space Invasions in the Lavatory: Suggestive Evidence for Arousal. Journal of Personality and Social Psychology, Vol. 33, No. 5, (str.541-546)

20. Milosavljević, B. (2005). Socijalna psihologija 1 i 2 Praktikum. Banja Luka: Filozofski fakultet Banja Luka

21. Milosavljević, B. (2007). Praktikum etiologija socijalne patologije. Banja Luka: Filozofski fakultet Banja Luka

22. MTD Training \& Ventus Publishing ApS. (2010). Advanced Communication Skills. United Kingdom: Autor

23. Pallant, J. (2009). SPSS: priručnik za preživljavanje. Beograd: Mikro knjiga (str. 97,238,243)

24. Pedersen, D.M. (1977). Factors Affectings Personal Space Toward a Group. Perceptual and Motor Skills, Vol 45(3, Pt 1), (str.735-743)

25. Pennington, D.C. (2006). Osnove socijalne psihologije. Jastrebarsko: Naklada Slap (str. 221, 224-225) 
26. Radenčić, Lj. (2013). Neverbalna komunikacija-Umijeće kvalitetnog nastavnika. Neobjavljeni diplomski rad. Zagreb: Odsjek za povijest Filozofskog fakulteta Sveučilišta u Zagrebu (str. 8)

27. Radošević, Ž. (2013). Povezanost religioznosti i negativnih socijalnopsiholoških konstrukata: autoritarnosti i dogmatizma. Neobjavljeni diplomski rad. Novi Sad: Odsjek za psihologiju Filozofskog fakulteta Univerziteta u Novom Sadu

28. Rijavec, M., Miljković, D. (2002.) NEVERBALNA KOMUNIKACIJA Jezik koji svi govorimo. Zagreb: IEP

29. Sindik, J. (2008). Poticajno okruženje i osobni prostor djece u dječjem vrtiću. Metodički obzori 3, (str.143-154)

30. Smith, E., Nolen-Hoeksema, S., Fredrickson, B. L., Loftus, G. R., Bem, D. J. i Maren, S. (2007). Atkinson/Hilgard Uvod u psihologiju. Jastrebarsko: Naklada Slap

31. Smith, K.E., Faig, K.E. (2014). The Role of Flexibility in Personal Space Preferences. The Journal of Neuroscience, Vol. 34, No. 3, (str.10135-10136)

32. Strube, M. J., Werner, C. M. (1984). Personal space claims as a function of interpersonal threat: The mediating role of need for control. Journal of Nonverbal Behavior, 9(1), (str.163-170)

33. Vejo, E., Adilović, M., Durmić, A. (2016). Religioznost i rizična ponašanja adolescenata u urbanim sredinama Federacije BiH. Sarajevo: Centar za dijalog - Vesatijja (str. 13,35)

34. Wolchover, N., (2012). Why Do We Have Personal Space?. Livescience http://www.livescience.com/20801-personal-space.html 
Original scientific article

\section{Safija Perviz, B.A.} \\ University of Bihac \\ Islamic Pedagogical Faculty \\ safijaperviz2017@gmail.com
}

\title{
DIFFERENCES IN THE SIZE OF PERSONAL SPACE IN REGARDS TO THE LEVEL OF RELIGIOUSNESS
}

\section{Abstract}

At the time of the original communities, when the most powerful instinct amongst humans was the instinct for survival, a man realized that he had a better chance if he joined one of the groups or tribes in which he lived at that time. Thus, despite fear for their lives, people were forced to communicate unconsciously using all channels of non-verbal communication. One of these channels is the interpersonal distance, that is the personal space. Personal space is determined by its factors, it performs functions that no other human mechanism performs and is marked by its bounds.

When humans satisfied all their needs, then the faith appeared, that is the human need for belief. This gave rise to today's religions and religiosity, and it occurs when the physiological needs are met. Religion and religiousness as a need ranks among the need for security and they are best manifested in people in desperate, dire, and in situations of general disaster, such as the loss of loved ones for example.

In this paper we will explain and define the notion of personal space and the notion of religion and religiosity, and then present the results of the research we received when these two phenomena broke through each other.

Keywords: personal space, non-verbal communication, religiosity 


$$
\text { كلية التربية الإسلامية بهاتش بريز }
$$

safijaperviz2017@gmail.com

الفروق بين حجم المساحة الشخصية نظرًا لدرجة التدين

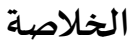

في زمن المجتمعات البدائية، عندما كانت الغزيرة الأقوى بين الناس غزيرة البقاء على في قيد الحياة، فقد أدرك الإنسان أن فرص النجاة أكبر إن انضمه إلى مجموعة أو قبيلة معينة

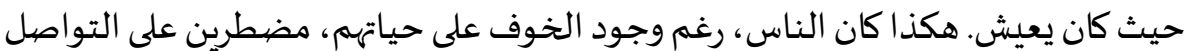
مع الآخرين، مستخدمين جميع قنوات التواصل غير اللفظي. ومن بين تلك القنوات المساحة

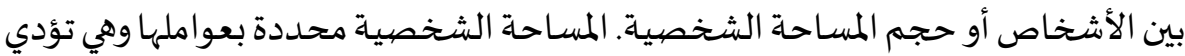

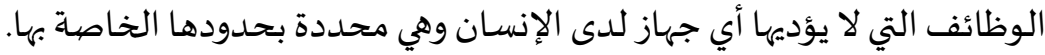

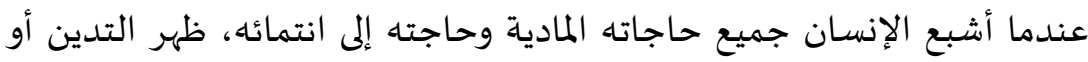

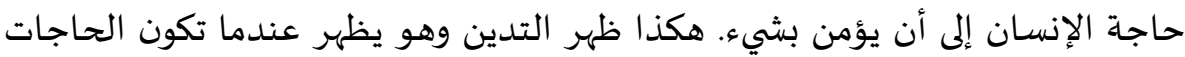
المادية مشبعة. الدين والتدين باعتبارهما حاجات تصنف في قسم الحاجات إلى إلى الأمن وهي

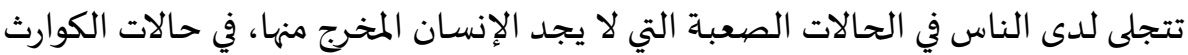
الكبيرة أو فقدان الأحبة وما شـابه ذلك.

في هذا البحث سنبين ونحدد مفهوم المساحة الشخصية ثم مفهوم الدين والتدين وبعد ذلك سنوضح نتائج البحث التي توصلنا إلها عندما مزجنا بين هاتين الظاهرتين

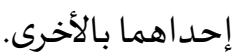
الكلمات الرئيسة: المساحة الشخصية، التواصل غير اللفظي، التدين 